\title{
Determination of Best and Worst Possibilities of Sub-Units of Drip Irrigation System on a Rectangular Field Considering Hydraulic and Economic Analysis
}

\author{
A.A.Kaneria ${ }^{1}$, T.M.V.Suryanarayana ${ }^{2}$ \\ ${ }^{\text {I}}$ P.G. Student, Water Resources Engineering and Management Institute, Faculty of Technology \& \\ Engineering,The Maharaja Sayajirao University of Baroda, Gujarat, India \\ ${ }^{2}$ Associate Professor, Water Resources Engineering and Management Institute, Faculty of Technology \& \\ Engineering,The Maharaja Sayajirao University of Baroda, Gujarat, India
}

\begin{abstract}
Amongst all the irrigation systems, Drip Irrigation System (DIS) offers highest application efficiency greater than $90 \%$ and it can be used for most of the crops in most of terrain. For better design, operation and control of DIS, division of field into several sub-units is best option. However, little information is available on division of field into sub-units. Sub-units are very useful in simplifying the DIS design for field as only for one sub-unit we need to design and then we can apply the same design to each and every sub-units. The objective of this study was to analyze the hydraulic results and economic results for different numbers of sub-unit on a rectangular field having area of 2 ha with two different fields one with length of $100 \mathrm{~m}$ and width of $200 \mathrm{~m}$ and other having length of $200 \mathrm{~m}$ and width of 100m, wherein other parameters like crop, infiltration rate, power availability, application efficiency, available discharge, temperature, evapotranspiration remains same. The study is carried out for two possibilities of source of water either at corner or at center. For hydraulic analysis head loss and head required at source is taken into consideration and for economic analysis only cost of pipes are taken into consideration because all other costs like operation cost and of cost other components remains almost same. For economic analysis laterals of LLDPE and manifold, submain and main are of PVC and HDPE material is considered.
\end{abstract}

Keywords: Drip Irrigation System, Best / Worst Sub-units, Hydraulic analysis, Economic Analysis, Rectangular Field

\section{Introduction}

Irrigation is essential for agriculture because water requirement of crop is supplied by precipitation but as we know precipitation is not uniformly distributed so whenever and wherever water requirement by crop is not fulfilled by precipitation then that requirement needs to fulfill artificially, by irrigation. As we know several irrigation methods are available for irrigation, selection of one depends upon many factors like type of crop, topography, water availability, soil characteristics, available cost etc. Among all the irrigation methods (Surface and Pressurized methods) available, DIS offers highest application efficiency greater than $90 \%$ though DIS is not widely used as all other traditional methods with application efficiency up to 60-70\% are being used because of high capital cost associated with DIS. Capital cost of DIS can be reduced by proper design which can be achieved by dividing field into sub-units but there can be many possibilities of dividing field into sub-units. For finding out best or optimum design, there is need of analyze all the possibilities. For that for all the hydraulic and economic results related with respective possible sub-units needs to compare and analyze. So objective of this study is to compare and analyze all the possible sub-unit size and its hydraulic and economic results for a rectangular field of dimension $100 \mathrm{~m} \times 200 \mathrm{~m}$ and $200 \mathrm{mx} 100 \mathrm{~m}$ with source of water either at corner or at center, to understand significance of sub-unit size on DIS design. For hydraulic analysis head loss and head required at source is taken into consideration and for economic analysis only pipe cost is considered as cost of all other components and operating cost are almost same. For economic analysis laterals of LLDP and manifold, submain, main of PVC and HDPE material is considered to compare the result of both the materials. For cost consideration guidelines of Gujarat Green Revolution Company Limited is followed.

Main reasons for partitioning field into sub-units

- Smaller the sub-unit better the control over application

- In case of limited availability of water field can be irrigated unit by unit

- Usually higher field size requires higher diameter pipe and also long length of pipe is required. Larger diameter and longer length tends to high head loss.

- By dividing field into sub-units smaller and shorter pipe will be required and thus reduction in head loss 


\section{Methodology}

For designing any irrigation system first parameter required is water requirement of field which depends on crop water requirement. Water requirement can be find out easily if reference crop evapotranspiration $\left(\mathrm{Et}_{\mathrm{o}}\right)$ and crop coefficient $\left(\mathrm{K}_{\mathrm{c}}\right)$ is known. For designing DIS also we need Net irrigation depth (NID) which is crop water requirement, then assuming application efficiency $98 \%$ we can find gross irrigation depth (GID) from NID. Maximum numbers of sub-units or sets in which field can be divided is depend upon power availability and required operation time, operation time depends upon GID, infiltration rate, emitter discharge, emitter spacing and power availability is generally taken as $12 \mathrm{hrs}$ because in India power availability for irrigation purpose in rural area is less than $12 \mathrm{hrs}$. In this study, Maximum number of field divisions came out to be 37. After determining maximum numbers of sub-units, one needs to design DIS for all the possible numbers of sub-units, sub-units cannot be prime number (one cannot divide field into 37 sub-units), and therefore the maximum numbers of the field divisions is considered to be 36 and similarly the minimum number is considered as 4 . From the sub-unit one can work out length of laterals, manifolds, submain and main then head loss is computed by Darcy-Weisbach equation and for finding friction factor Churchill's equation is used, at the end of design head required at source should be less than $40 \mathrm{~m}$ because components considered for this study are of grade 4 so if at the end head required at source is more than $40 \mathrm{~m}$ then one needs to redesign the DIS. For the economic analysis laterals are of LLDPE material and manifolds, submains and mains are of PVC \& HDPE material are considered. The range of diameter for various components used in this study is given in Table 1

Table 1: Range of Diameter of Different Components

\begin{tabular}{|l|l|l|}
\hline Sr.no & System Component & Range of Diameter of pipe, $\mathbf{~ m m}$ \\
\hline 1 & Lateral & $12,16,20,25$ \\
\hline 2 & Manifold, Submain & $20,25,32,40,50,63,75,90,110,125$ \\
\hline 3 & Main & $32,40,50,63,73,90,110,125$ \\
\hline
\end{tabular}

Table 2: Various sub-possibilities For 36 Sub-Units

\begin{tabular}{|l|l|l|}
\hline $\begin{array}{l}\text { Number } \\
\text { of Sub-Units }\end{array}$ & Column & Row \\
\hline 36 & 18 & 2 \\
\cline { 2 - 3 } & 2 & 18 \\
\cline { 2 - 3 } & 12 & 3 \\
\cline { 2 - 3 } & 3 & 12 \\
\cline { 2 - 3 } & 9 & 4 \\
\cline { 2 - 3 } & 4 & 9 \\
\cline { 2 - 3 } & 6 & 6 \\
\hline
\end{tabular}

As shown in Table 2 for 36 sub-units, several combinations of columns and rows are possible, similarly for all other possible numbers of sub-units, various combination are considered and thus 69 possible designs for DIS are worked out for carrying out hydraulic and economic analysis of DIS design.

\section{EconomicAnalysis}

For economic analysis of DIS only cost of pipes are taken into consideration as it is a variable costs. Following equation is used for finding out cost of DIS,

Cost $=\left(\mathrm{C}_{\mathrm{L}} * \mathrm{~L}_{\mathrm{L}} * \mathrm{~N}_{\mathrm{L}} * \mathrm{~N}_{\mathrm{SU}}\right)+\left(\mathrm{C}_{\mathrm{Mn}} * \mathrm{~L}_{\mathrm{Mn}} * \mathrm{~N}_{\mathrm{Mn}}\right)+\left(\mathrm{C}_{\mathrm{S}} * \mathrm{~L}_{\mathrm{S}} * \mathrm{~N}_{\mathrm{S}}\right)+\left(\mathrm{C}_{\mathrm{M}} * \mathrm{~L}_{\mathrm{M}} * \mathrm{~N}_{\mathrm{M}}\right)$

Where,

$\mathrm{C}_{\mathrm{L}}, \mathrm{C}_{\mathrm{Mn}}, \mathrm{C}_{\mathrm{S}}, \mathrm{C}_{\mathrm{M}}$ are unit cost of lateral, manifold, submain and main respectively

$\mathrm{L}_{\mathrm{L}}, \mathrm{L}_{\mathrm{Mn}}, \mathrm{L}_{\mathrm{S}}, \mathrm{L}_{\mathrm{M}}$ are length of lateral, manifold, submain and main respectively

$\mathrm{N}_{\mathrm{L}}$ is nos. of laterals in one sub-unit

$\mathrm{N}_{\mathrm{SU}}$ is total nos. of sub-units

$\mathrm{N}_{\mathrm{Mn}}, \mathrm{N}_{\mathrm{S}}, \mathrm{N}_{\mathrm{M}}$ is nos. of manifold, submain and main in system respectively

Cases considered for this study are as following,

Case-1 field having length of $100 \mathrm{~m}$ and width of $200 \mathrm{~m}$ and source of water at corner

Case-2 field having length of $100 \mathrm{~m}$ and width of $200 \mathrm{~m}$ and source of water at center

Case-3 field having length of $200 \mathrm{~m}$ and width of $100 \mathrm{~m}$ and source of water at corner

Case-4 field having length of $200 \mathrm{~m}$ and width of $100 \mathrm{~m}$ and source of water at center

For DIS design, layout of all the components is very important which is governed by numbers of sub-units selected for a field division and it also depends on combination of columns and rows selected for particular number of sub-unit. Figure 1 shows design layout of various sub-possibilities of 10 sub-units, which is one of the best hydraulic designs, as for case 1 and case 2 and figure 2 shows various layouts for 30 sub-units which is one of the best economical design, as for case 3 and case 4 


\section{Design Layout}

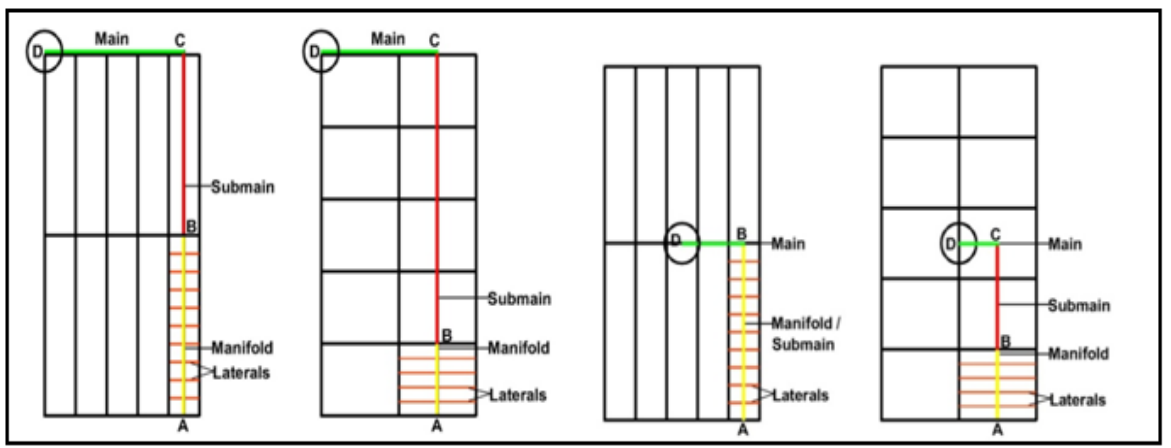

Fig.1: Design Layout For Field of Dimension 100m x 200m with Location of Source of Water at Corner and at Center, Having 10 Sub-units

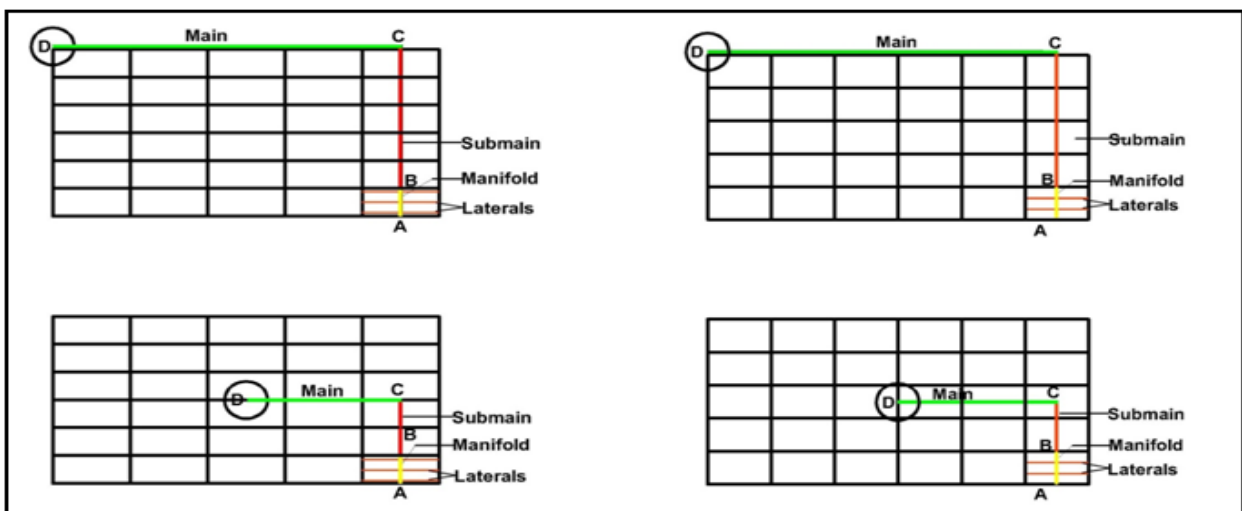

Fig.2: Design Layout For Field of Dimension 200m x 100m with Location of Source of Water at Corner and at Center, Having 30 Sub-units

\section{Input Data}

Table 3: Input Data for Study

\begin{tabular}{|l|l|}
\hline Field Size $\left.\mathbf{( m}^{\mathbf{2}}\right)$ & $100 \times 200 / 200 \times 100$ \\
\hline Source Location & Corner/Center \\
\hline Crop Spacing (m) & 0.5 \\
\hline Row Spacing (m) & 0.6 \\
\hline infiltration rate (mm/hr) & 25 \\
\hline $\mathbf{E t}_{\mathbf{~}}$ (mm/day) & 5 \\
\hline $\mathbf{K}_{\mathbf{c}}$ & 1 \\
\hline Emitter Discharge (lph) & 4 \\
\hline Appli. Efficiency (\%) & 98 \\
\hline Power availability (hr) & 12 \\
\hline Temperature ( $\left.{ }^{\mathbf{0}} \mathbf{C}\right)$ & 27 \\
\hline
\end{tabular}

\section{Assumptions}

- At a time only one sub-unit is irrigated

- Diameter of manifold and submain is kept same, hence if there is need to change in diameter of manifold, diameter of submain also changes and vice versa

- Diameter of main is taken equal to or greater than diameter of submain

- First emitter is considered at half spacing from manifold

- Inline emitter is taken into consideration for this study

- Field considered have negligible slope

\section{Results \& Analysis}

In this study four different cases are taken into consideration as we can see in input data. For the data given in Table 3 maximum 37 numbers of sub-units worked out. As stated earlier sub-units cannot be prime number so in all the cases maximum 36 sub-units can be possible which means we cannot divide field into more than 36 number. So starting from 36 and ending at 4 all the possibilities with various sub-possibilities had been worked out and it is found out that total 69 possibilities are under each case. For an economic comparison cost 
of PVC material is considered because as shown in table 3 to table 18 cost of DIS design with DIS design with HDPE material is $0.5 \%$ to $25.6 \%$ more costly than design with PVC material. Form the study following results are obtained

For first case, as shown in Table 4, 5, 6, 7 field having length of $100 \mathrm{~m}$ and width of $200 \mathrm{~m}$ and source of water at corner, according to hydraulic parameters for best design one needs to divide field into 28 sub-units having 14 columns and 2 rows, for this design head loss is $4.4662 \mathrm{~m}$ and head required at source is $21.9109 \mathrm{~m}$ with cost for PVC is RS. 3,96,278 and for HDPE is Rs.4,67,473. Whereas worst design according to hydraulic parameters is found out for field division into 35 with 7 columns and 5 rows, for this head loss is $20.8581 \mathrm{~m}$ and head required source is $39.9361 \mathrm{~m}$ with cost of Rs.3,12,817 and Rs.3,34,235 for PVC and HDPE respectively. According to economic results best design is found out for field division into 24 with 3 columns and 8 rows having head loss of $17.1796 \mathrm{~m}$ and head required at source is $35.8048 \mathrm{~m}$ with cost of PVC is Rs.3,12,817 and cost of HDPE is Rs.3,34,235 and economically worst result is found for field division into 36 with 18 columns and 2 rows having head loss of $10.5421 \mathrm{~m}$ and head required at source is $28.5951 \mathrm{~m}$ with cost of PVC is Rs. 4,14,130 and HDPE is Rs. 4,36,572.

For second, as shown in Table 8, 9, 10, 11 field having length of $100 \mathrm{~m}$ and width of $200 \mathrm{~m}$ and source of water at center, according to hydraulic parameters for best design one needs to divide field into 28 sub-units having 14 columns and 2 rows, for this design head loss is $1.5718 \mathrm{~m}$ and head required at source is $18.7271 \mathrm{~m}$ with cost for PVC is RS. 3,96,121 and for HDPE is Rs.4,67,226. Whereas worst design according to hydraulic parameters is found out for field division into 26 with 2 columns and 13 rows, for this head loss is $20.8808 \mathrm{~m}$ and head required at source is $39.9044 \mathrm{~m}$ with cost of Rs.3,43,172 and Rs.3,46,189 for PVC and HDPE respectively. According to economic results best design is found out for field division into 27 with 3 columns and 9 rows having head loss of $19.1053 \mathrm{~m}$ and head required at source is $37.9230 \mathrm{~m}$ with cost of PVC is Rs.2,85,447 and cost of HDPE is Rs.2,89,913 and economically worst result is found for field division into 36 with 18 columns and 2 rows having head loss of $3.7232 \mathrm{~m}$ and head required at source is $21.0943 \mathrm{~m}$ with cost of PVC is Rs. 4,14,020 and HDPE is Rs. 4,36,445.

For third case, as shown in Table 12, 13, 14, 15 field having length of $200 \mathrm{~m}$ and width of $100 \mathrm{~m}$ and source of water at corner, according to hydraulic parameters for best design one needs to divide field into 20 sub-units having 10 columns and 2 rows, for this design head loss is $9.5449 \mathrm{~m}$ and head required at source is $27.4761 \mathrm{~m}$ with cost for PVC is RS. 3,19,882 and for HDPE is Rs.3,49,132. Whereas worst design according to hydraulic parameters is found out for field division into 28 with 4 columns and 7 rows, for this head loss is $20.8632 \mathrm{~m}$ and head required at source is $39.8851 \mathrm{~m}$ with cost of Rs.2,87,210 and Rs.2,94,220 for PVC and HDPE respectively. According to economic results best design is found out for field division into 28 with 4 columns and 7 rows having head loss of $20.8632 \mathrm{~m}$ and head required at source is $39.8851 \mathrm{~m}$ with cost of PVC is Rs.2,87,210 and cost of HDPE is Rs.2,94,220 and economically worst result is found for field division into 4 with 2 columns and 2 rows having head loss of $10.1861 \mathrm{~m}$ and head required at source is $28.0686 \mathrm{~m}$ with cost of PVC is Rs. 4,01,711 and HDPE is Rs. 4,46,693.

For fourth case, as shown in Table 16, 17, 18, 19 field having length of $200 \mathrm{~m}$ and width of $100 \mathrm{~m}$ and source of water at center, according to hydraulic parameters for best design one needs to divide field into 4 subunits having 4 columns and 2 rows, for this design head loss is $3.5011 \mathrm{~m}$ and head required at source is 20.7151 $\mathrm{m}$ with cost for PVC is RS. 3,95,378 and for HDPE is Rs.4,33,934. Whereas worst design according to hydraulic parameters is found out for field division into 15 with 3 columns and 5 rows, for this head loss is $20.7054 \mathrm{~m}$ and head required at source is $39.6328 \mathrm{~m}$ with cost of Rs.4,30,784 and Rs.4,34,415 for PVC and HDPE respectively. According to economic results best design is found out for field division into 35 with 5 columns and 7 rows having head loss of $15.7852 \mathrm{~m}$ and head required at source is $34.2083 \mathrm{~m}$ with cost of PVC is Rs.2,86,256 and cost of HDPE is Rs.2,90,725 and economically worst result is found for field division into 15 with 3 columns and 3 rows having head loss of $20.7054 \mathrm{~m}$ and head required at source is $39.6328 \mathrm{~m}$ with cost of PVC is Rs. 4,30,784 and HDPE is Rs.4,34,415

Table 4: Hydraulically best designs for field size $100 \mathrm{~m}$ x 200m when source at corner

\begin{tabular}{|l|l|l|l|l|l|l|l|l|}
\hline Corner & & $\begin{array}{l}\text { Head Loss } \\
(\mathrm{m})\end{array}$ & $\begin{array}{l}\text { Head at Source } \\
(\mathrm{m})\end{array}$ & $\begin{array}{l}\text { PVC Cost } \\
\text { (Rs.) }\end{array}$ & $\begin{array}{l}\text { HDPE Cost } \\
(\text { Rs.) }\end{array}$ & Difference & \% Increase \\
\hline $\begin{array}{l}\text { No of } \\
\text { Sub-units }\end{array}$ & Column & Row & & & \\
\hline 30 & 15 & 2 & 4.4714 & 21.9168 & 400289.503 & 476406.389 & 76116.886 & 19.0155 \\
\hline 28 & 14 & 2 & 4.4662 & 21.9109 & 396279.500 & 467473.012 & 71193.512 & 17.9655 \\
\hline 26 & 13 & 2 & 5.6634 & 23.2275 & 382138.042 & 448410.638 & 66272.596 & 17.3426 \\
\hline 24 & 12 & 2 & 5.6545 & 23.2174 & 378657.106 & 440003.870 & 61346.764 & 16.2011 \\
\hline 10 & 5 & 2 & 5.2826 & 22.7875 & 363132.600 & 451967.600 & 88835.000 & 24.4635 \\
\hline
\end{tabular}


Determination of Best and Worst Possibilities of Sub-Units of Drip Irrigation System on a

Table 5: Economically best designs for field size $100 \mathrm{~m}$ x 200m when source at corner

\begin{tabular}{|l|l|l|l|l|l|l|l|l|}
\hline Corner & & $\begin{array}{l}\text { Head Loss } \\
(\mathbf{m})\end{array}$ & $\begin{array}{l}\text { Head at Source } \\
(\mathbf{m})\end{array}$ & $\begin{array}{l}\text { PVC Cost } \\
\text { (Rs.) }\end{array}$ & $\begin{array}{l}\text { HDPE Cost } \\
\text { (Rs.) }\end{array}$ & Difference & \% Increase \\
\hline $\begin{array}{l}\text { No of } \\
\text { Sub-units }\end{array}$ & Column & Row & 296119.828 & 300267.459 & 4147.631 & 1.4007 \\
\hline 33 & 3 & 11 & 12.8500 & 31.0433 & 2967 & 1.4026 \\
\hline 30 & 3 & 10 & 15.0727 & 33.4872 & 295718.527 & 299866.158 & 4147.631 & 1.4102 \\
\hline 27 & 3 & 9 & 17.8486 & 36.5407 & 294113.323 & 298260.954 & 4147.631 & 1.41 \\
\hline 24 & 3 & 8 & 17.1796 & 35.8048 & 293702.231 & 299391.745 & 5689.514 & 1.9372 \\
\hline 21 & 3 & 7 & 20.0364 & 38.9473 & 296280.678 & 305209.056 & 8928.378 & 3.0135 \\
\hline
\end{tabular}

Table 6: Hydraulically worst designs for field size $100 \mathrm{~m}$ x $200 \mathrm{~m}$ when source at corner

\begin{tabular}{|l|l|l|l|l|l|l|l|l|}
\hline Corner \\
\hline $\begin{array}{l}\text { No of } \\
\text { Sub-units }\end{array}$ & Column & Row & $\begin{array}{l}\text { Head Loss } \\
(\mathbf{m})\end{array}$ & $\begin{array}{l}\text { Head at Source } \\
(\mathbf{m})\end{array}$ & $\begin{array}{l}\text { PVC Cost } \\
\text { (Rs.) }\end{array}$ & $\begin{array}{l}\text { HDPE Cost } \\
\text { (Rs.) }\end{array}$ & Difference & \% Increase \\
\hline 35 & 7 & 5 & 20.8581 & 39.9361 & 312817.219 & 334234.727 & 21417.508 & 6.8467 \\
\hline 25 & 5 & 5 & 20.1209 & 39.1097 & 309158.600 & 315774.900 & 6616.300 & 2.1401 \\
\hline 22 & 2 & 11 & 20.8337 & 39.8526 & 353844.250 & 358115.750 & 4271.500 & 1.2072 \\
\hline 20 & 4 & 5 & 20.4556 & 39.4582 & 305503.000 & 317490.250 & 11987.250 & 3.9238 \\
\hline 8 & 2 & 4 & 20.6959 & 39.7000 & 363071.750 & 389985.250 & 26913.500 & 7.4127 \\
\hline
\end{tabular}

Table 7: Economically worst designs for field size $100 \mathrm{~m}$ x 200m when source at corner

\begin{tabular}{|l|l|l|l|l|l|l|l|l|}
\hline Corner & \multicolumn{9}{|l|}{$\begin{array}{l}\text { Head ad at } \\
\text { No of Sub- } \\
\text { units }\end{array}$} & Column & Row & $\begin{array}{l}\text { Head Loss Cost } \\
\text { (m) }\end{array}$ & $\begin{array}{l}\text { HDPE Cost } \\
\text { Source (m) } \\
\text { (Rs.) }\end{array}$ & Difference & $\begin{array}{l}\text { \% } \\
\text { Increase }\end{array}$ \\
\hline 36 & 18 & 2 & 10.5421 & 28.5951 & 414129.852 & 436571.856 & 22442.004 & 5.4191 \\
\hline 34 & 17 & 2 & 10.5378 & 28.5902 & 400399.797 & 421627.194 & 21227.397 & 5.3016 \\
\hline 32 & 16 & 2 & 10.5290 & 28.5805 & 394134.337 & 414146.520 & 20012.183 & 5.0775 \\
\hline 30 & 15 & 2 & 4.4714 & 21.9168 & 400289.503 & 476406.389 & 76116.886 & 19.0155 \\
\hline 28 & 14 & 2 & 4.4662 & 21.9109 & 396279.500 & 467473.012 & 71193.512 & 17.9655 \\
\hline
\end{tabular}

Table 8: Hydraulically best designs for field size $100 \mathrm{~m}$ x $200 \mathrm{~m}$ when source at center

\begin{tabular}{|l|l|l|l|l|l|l|l|l|}
\hline Center \\
\hline $\begin{array}{l}\text { No of } \\
\text { Sub-units }\end{array}$ & Column & Row & $\begin{array}{l}\text { Head } \\
\text { Loss (m) }\end{array}$ & $\begin{array}{l}\text { Head at at } \\
\text { Source (m) }\end{array}$ & $\begin{array}{l}\text { PVC Cost } \\
(\text { Rs.) }\end{array}$ & $\begin{array}{l}\text { HDPE Cost } \\
\text { (Rs.) }\end{array}$ & Difference & $\begin{array}{l}\text { \% } \\
\text { Increase }\end{array}$ \\
\hline 30 & 15 & 2 & 1.5770 & 18.7330 & 400144.336 & 476180.108 & 76035.772 & 19.0021 \\
\hline 28 & 14 & 2 & 1.5718 & 18.7271 & 396121.136 & 467226.160 & 71105.024 & 17.9503 \\
\hline 24 & 12 & 2 & 1.9807 & 19.1763 & 378472.348 & 439715.876 & 61243.528 & 16.1818 \\
\hline 10 & 5 & 2 & 1.8034 & 18.9604 & 362248.200 & 450268.200 & 88020.000 & 24.2983 \\
\hline 6 & 3 & 2 & 1.7488 & 18.8309 & 346192.200 & 424941.228 & 78749.028 & 22.7472 \\
\hline
\end{tabular}

Table 9: Economically best designs for field size $100 \mathrm{~m}$ x $200 \mathrm{~m}$ when source at center

\begin{tabular}{|l|l|l|l|l|l|l|l|l|}
\hline Center & \multicolumn{1}{|l|}{} \\
\hline $\begin{array}{l}\text { No of } \\
\text { Sub-units }\end{array}$ & Column & Row & $\begin{array}{l}\text { Head } \\
\text { Loss (m) }\end{array}$ & $\begin{array}{l}\text { Head at } \\
\text { Source (m) }\end{array}$ & $\begin{array}{l}\text { PVC Cost } \\
\text { (Rs.) }\end{array}$ & $\begin{array}{l}\text { HDPE Cost } \\
\text { (Rs.) }\end{array}$ & Difference & $\begin{array}{l}\text { \% } \\
\text { Increase }\end{array}$ \\
\hline 36 & 3 & 12 & 14.7591 & 33.1422 & 286965.876 & 291478.758 & 4512.882 & 1.5726 \\
\hline 33 & 3 & 11 & 17.0120 & 35.6204 & 286564.575 & 291077.457 & 4512.882 & 1.5748 \\
\hline 32 & 4 & 8 & 17.7124 & 36.4406 & 288629.500 & 294553.250 & 5923.750 & 2.0524 \\
\hline 30 & 3 & 10 & 19.8792 & 38.7743 & 286163.274 & 290676.156 & 4512.882 & 1.5770 \\
\hline 27 & 3 & 9 & 19.1053 & 37.9230 & 285447.180 & 289913.442 & 4466.262 & 1.5647 \\
\hline
\end{tabular}

Table 10: Hydraulically worst designs for field size $100 \mathrm{~m}$ x $200 \mathrm{~m}$ when source at center

\begin{tabular}{|c|c|c|c|c|c|c|c|c|}
\hline \multicolumn{9}{|l|}{ Center } \\
\hline $\begin{array}{l}\text { No of } \\
\text { Sub-units }\end{array}$ & Column & Row & $\begin{array}{l}\text { Head } \\
\text { Loss (m) }\end{array}$ & $\begin{array}{l}\text { Head at } \\
\text { Source (m) }\end{array}$ & $\begin{array}{l}\text { PVC Cost } \\
\text { (Rs.) }\end{array}$ & $\begin{array}{l}\text { HDPE Cost } \\
\text { (Rs.) }\end{array}$ & Difference & $\begin{array}{l}\text { \% } \\
\text { Increase }\end{array}$ \\
\hline 30 & 3 & 10 & 19.8792 & 38.7743 & 286163.274 & 290676.156 & 4512.882 & 1.5770 \\
\hline 28 & 2 & 14 & 18.8834 & 37.7073 & 347668.500 & 350680.000 & 3011.500 & 0.8662 \\
\hline 27 & 3 & 9 & 19.1053 & 37.9230 & 285447.180 & 289913.442 & 4466.262 & 1.5647 \\
\hline 26 & 2 & 13 & 20.8808 & 39.9044 & 343177.500 & 346189.000 & 3011.500 & 0.8775 \\
\hline 16 & 2 & 8 & 18.5978 & 37.3931 & 349016.500 & 351748.000 & 2731.500 & 0.7826 \\
\hline
\end{tabular}

Table 11: Economically worst designs for field size $100 \mathrm{~m}$ x $200 \mathrm{~m}$ when source at center

\begin{tabular}{|l|l|l|l|l|l|l|l|l|}
\hline Center & \multicolumn{9}{|l|}{$\mid \begin{array}{l}\text { Head at } \\
\text { No of } \\
\text { Sub-units }\end{array}$} & Column & Row & $\begin{array}{l}\text { Head Loss } \\
(\mathbf{m})\end{array}$ & $\begin{array}{l}\text { PVC Cost } \\
\text { Source (m) }\end{array}$ & $\begin{array}{l}\text { HDPE Cost } \\
(\text { Rs.) }\end{array}$ & Difference & $\begin{array}{l}\text { \% } \\
\text { Increase }\end{array}$ \\
\hline 36 & 18 & 2 & 3.7232 & 21.0943 & 414019.840 & 436444.848 & 22425.008 & 5.4164 \\
\hline 34 & 17 & 2 & 3.7188 & 21.0984 & 400285.856 & 421495.650 & 21209.794 & 5.2987 \\
\hline 32 & 16 & 2 & 3.7101 & 21.0797 & 394012.538 & 414005.904 & 19993.366 & 5.0743 \\
\hline 30 & 15 & 2 & 1.5770 & 18.7330 & 400144.336 & 476180.108 & 76035.772 & 19.0021 \\
\hline 28 & 14 & 2 & 1.5718 & 18.7271 & 396121.136 & 467226.160 & 71105.024 & 17.9503 \\
\hline
\end{tabular}


Determination of Best and Worst Possibilities of Sub-Units of Drip Irrigation System on a

Table 12: Hydraulically best designs for field size $200 \mathrm{~m} \times 100 \mathrm{~m}$ when source at corner

\begin{tabular}{|l|l|l|l|l|l|l|l|l|}
\hline Corner \\
\hline $\begin{array}{l}\text { No of } \\
\text { Sub-units }\end{array}$ & Column & Row & $\begin{array}{l}\text { Head } \\
\text { Loss (m) }\end{array}$ & $\begin{array}{l}\text { Head ad at } \\
\text { Source (m) }\end{array}$ & $\begin{array}{l}\text { PVC Cost } \\
\text { (Rs.) }\end{array}$ & $\begin{array}{l}\text { HDPE Cost } \\
\text { (Rs.) }\end{array}$ & Difference & $\begin{array}{l}\text { \% } \\
\text { Increase }\end{array}$ \\
\hline 36 & 18 & 2 & 10.2656 & 28.2888 & 348034.248 & 360140.256 & 12106.008 & 3.4784 \\
\hline 25 & 5 & 5 & 11.7223 & 29.7392 & 295898.200 & 303357.600 & 7459.400 & 2.5209 \\
\hline 24 & 12 & 2 & 11.0810 & 29.1747 & 322044.747 & 334040.733 & 11995.986 & 3.7249 \\
\hline 20 & 10 & 2 & 9.5449 & 27.4761 & 319882.100 & 349132.300 & 29250.200 & 9.1441 \\
\hline 4 & 2 & 2 & 10.1861 & 28.0686 & 401711.000 & 446693.000 & 44982.000 & 11.1976 \\
\hline
\end{tabular}

Table 13: Economically best designs for field size $200 \mathrm{~m}$ x $100 \mathrm{~m}$ when source at corner

\begin{tabular}{|l|l|l|l|l|l|l|l|l|}
\hline Corner & Column & Row & $\begin{array}{l}\text { Head } \\
\text { Loss (m) } \\
\text { Sub-units }\end{array}$ & $\begin{array}{l}\text { Head at } \\
\text { Source (m) }\end{array}$ & $\begin{array}{l}\text { PVC Cost } \\
(\text { Rs.) }\end{array}$ & $\begin{array}{l}\text { HDPE Cost } \\
(\text { Rs.) }\end{array}$ & Row & $\begin{array}{l}\text { Head } \\
\text { Loss (m) }\end{array}$ \\
\hline 36 & 6 & 6 & 18.0923 & 36.8088 & 292440.129 & 297614.760 & 5174.631 & 1.769 \\
\hline 35 & 5 & 7 & 19.6287 & 38.4362 & 289178.200 & 293655.800 & 4477.600 & 1.548 \\
\hline 30 & 6 & 5 & 17.6985 & 36.3756 & 292499.037 & 301066.551 & 8567.514 & 2.929 \\
\hline 30 & 5 & 6 & 18.6296 & 37.3372 & 290024.200 & 297833.600 & 7809.400 & 2.693 \\
\hline 28 & 4 & 7 & 20.8632 & 39.8851 & 287210.250 & 294219.750 & 7009.500 & 2.441 \\
\hline
\end{tabular}

Table 14: Hydraulically worst designs for field size $200 \mathrm{~m}$ x $100 \mathrm{~m}$ when source at corner

\begin{tabular}{|l|l|l|l|l|l|l|l|l|}
\hline Corner \\
\begin{tabular}{|l|l|l|l|l|l|} 
No of \\
Sub-units
\end{tabular} & Column & Row & $\begin{array}{l}\text { Head } \\
\text { Loss (m) }\end{array}$ & $\begin{array}{l}\text { Head at at } \\
\text { Source (m) }\end{array}$ & $\begin{array}{l}\text { PVC Cost } \\
\text { (Rs.) }\end{array}$ & $\begin{array}{l}\text { HDPE Cost } \\
\text { (Rs.) }\end{array}$ & Difference & $\begin{array}{l}\text { \% } \\
\text { Increase }\end{array}$ \\
\hline 28 & 4 & 7 & 20.8632 & 39.8851 & 287210.250 & 294219.750 & 7009.500 & 2.441 \\
\hline 24 & 2 & 12 & 20.8487 & 39.7974 & 373271.500 & 375396.000 & 2124.500 & 0.569 \\
\hline 18 & 3 & 6 & 20.6233 & 39.5425 & 354112.805 & 360031.291 & 5918.486 & 1.671 \\
\hline 14 & 2 & 7 & 20.8065 & 39.7510 & 386377.000 & 406869.000 & 20492.000 & 5.304 \\
\hline 8 & 4 & 2 & 20.6959 & 39.7010 & 369332.750 & 401912.250 & 32579.500 & 8.821 \\
\hline
\end{tabular}

Table 15: Economically worst designs for field size $200 \mathrm{~m}$ x $100 \mathrm{~m}$ when source at corner

\begin{tabular}{|l|l|l|l|l|l|l|l|l|}
\hline Corner \\
\hline $\begin{array}{l}\text { No of } \\
\text { Sub-units }\end{array}$ & Column & Row & $\begin{array}{l}\text { Head } \\
\text { Loss (m) }\end{array}$ & $\begin{array}{l}\text { Head at } \\
\text { Source (m) }\end{array}$ & $\begin{array}{l}\text { PVC Cost } \\
(\text { Rs.) }\end{array}$ & $\begin{array}{l}\text { HDPE Cost } \\
\text { (Rs.) }\end{array}$ & Difference & $\begin{array}{l}\text { \% } \\
\text { Increase }\end{array}$ \\
\hline 14 & 2 & 7 & 20.8065 & 39.7510 & 386377.000 & 406869.000 & 20492.000 & 5.304 \\
\hline 12 & 2 & 6 & 14.9478 & 33.3064 & 377709.500 & 391124.500 & 13415.000 & 3.552 \\
\hline 8 & 2 & 4 & 20.0060 & 38.8705 & 377153.500 & 396984.500 & 19831.000 & 5.258 \\
\hline 6 & 2 & 3 & 13.8029 & 32.0470 & 387264.000 & 415789.000 & 28525.000 & 7.366 \\
\hline 4 & 2 & 2 & 10.1861 & 28.0686 & 401711.000 & 446693.000 & 44982.000 & 11.198 \\
\hline
\end{tabular}

Table 16: Hydraulically best designs for field size $200 \mathrm{~m} \times 100 \mathrm{~m}$ when source at center

\begin{tabular}{|l|l|l|l|l|l|l|l|l|}
\hline Center & \multicolumn{9}{|l|}{} \\
\hline $\begin{array}{l}\text { No of } \\
\text { Sub-units }\end{array}$ & Column & Row & $\begin{array}{l}\text { Head Loss } \\
(\mathbf{m})\end{array}$ & $\begin{array}{l}\text { Head at arference } \\
\text { Source (m) }\end{array}$ & $\begin{array}{l}\text { PVC Cost } \\
\text { (Rs.) }\end{array}$ & $\begin{array}{l}\text { HDPE Cost } \\
\text { (Rs.) }\end{array}$ & Diffease \\
\hline 36 & 18 & 2 & 4.3964 & 21.8327 & 347814.224 & 359886.240 & 12072.016 & 3.471 \\
\hline 20 & 10 & 2 & 4.0383 & 21.4189 & 319442.200 & 348446.600 & 29004.400 & 9.080 \\
\hline 18 & 9 & 2 & 4.7538 & 22.1986 & 314678.888 & 341171.212 & 26492.324 & 8.419 \\
\hline 6 & 2 & 3 & 5.0601 & 22.4299 & 382842.000 & 407292.000 & 24450.000 & 6.386 \\
\hline 4 & 2 & 2 & 3.5011 & 20.7151 & 395378.000 & 433934.000 & 38556.000 & 9.752 \\
\hline
\end{tabular}

Table 17: Economically best designs for field size $200 \mathrm{~m} \times 100 \mathrm{~m}$ when source at center

\begin{tabular}{|l|l|l|l|l|l|l|l|l|}
\hline Center \\
\hline $\begin{array}{l}\text { No of } \\
\text { Sub-units }\end{array}$ & Column & Row & $\begin{array}{l}\text { Head } \\
\text { Loss (m) }\end{array}$ & $\begin{array}{l}\text { Head ad arce (m) } \\
\text { Source }\end{array}$ & $\begin{array}{l}\text { PVC Cost } \\
\text { (Rs.) }\end{array}$ & $\begin{array}{l}\text { HDPE Cost } \\
\text { (Rs.) }\end{array}$ & Difference & $\begin{array}{l}\text { \% } \\
\text { Increase }\end{array}$ \\
\hline 36 & 6 & 6 & 14.7591 & 33.1422 & 289559.876 & 294749.758 & 5189.8820 & 1.7923 \\
\hline 35 & 5 & 7 & 15.7852 & 34.2083 & 286256.400 & 290724.600 & 4468.2000 & 1.5609 \\
\hline 30 & 6 & 5 & 19.8792 & 38.7743 & 288757.274 & 293947.156 & 5189.8820 & 1.7973 \\
\hline 30 & 5 & 6 & 20.3739 & 39.2559 & 286256.400 & 290724.600 & 4468.2000 & 1.5609 \\
\hline 28 & 7 & 4 & 12.0539 & 30.1958 & 291090.238 & 296869.636 & 5779.3980 & 1.9854 \\
\hline
\end{tabular}

Table 18: Hydraulically worst designs for field size $200 \mathrm{~m}$ x $100 \mathrm{~m}$ when source at center

\begin{tabular}{|l|l|l|l|l|l|l|l|l|}
\hline Center & Rolumn & Row & $\begin{array}{l}\text { Head } \\
\text { Loss (m) }\end{array}$ & $\begin{array}{l}\text { Head at } \\
\text { Source (m) }\end{array}$ & $\begin{array}{l}\text { PVC Cost } \\
\text { (Rs.) }\end{array}$ & $\begin{array}{l}\text { HDPE Cost } \\
\text { (Rs.) }\end{array}$ & Difference & $\begin{array}{l}\text { \% } \\
\text { Increase }\end{array}$ \\
\hline 30 & 5 & 6 & 20.3739 & 39.2559 & 286256.400 & 290724.600 & 4468.200 & 1.561 \\
\hline 20 & 2 & 10 & 20.5886 & 39.5113 & 362217.000 & 364178.000 & 1961.000 & 0.541 \\
\hline 16 & 4 & 4 & 18.5978 & 37.3931 & 352945.500 & 356284.000 & 3338.500 & 0.946 \\
\hline 15 & 3 & 5 & 20.7054 & 39.6328 & 430784.116 & 433414.854 & 2630.738 & 0.611 \\
\hline 14 & 2 & 7 & 20.4153 & 39.3207 & 371307.000 & 373128.000 & 1821.000 & 0.490 \\
\hline
\end{tabular}


Determination of Best and Worst Possibilities of Sub-Units of Drip Irrigation System on a

Table 19: Economically worst designs for field size $200 \mathrm{~m}$ x $100 \mathrm{~m}$ when source at center

\begin{tabular}{|c|c|c|c|c|c|c|c|c|}
\hline $\begin{array}{l}\text { No of } \\
\text { Sub-units }\end{array}$ & Column & Row & $\begin{array}{l}\text { Head } \\
\text { Loss (m) }\end{array}$ & $\begin{array}{l}\text { Head at } \\
\text { Source }(\mathrm{m})\end{array}$ & $\begin{array}{l}\text { PVC Cost } \\
\text { (Rs.) }\end{array}$ & $\begin{array}{l}\text { HDPE Cost } \\
\text { (Rs.) }\end{array}$ & Difference & $\begin{array}{l}\% \\
\text { Increase }\end{array}$ \\
\hline 36 & 2 & 18 & 12.4105 & 30.5154 & 373722.000 & 375753.000 & 2031.000 & 0.543 \\
\hline 15 & 3 & 5 & 20.7054 & 39.6328 & 430784.116 & 433414.854 & 2630.738 & 0.611 \\
\hline 8 & 2 & 4 & 7.4963 & 25.1098 & 374023.000 & 391021.000 & 16998.000 & 4.545 \\
\hline 6 & 2 & 3 & 5.0601 & 22.4299 & 382842.000 & 407292.000 & 24450.000 & 6.386 \\
\hline 4 & 2 & 2 & 3.5011 & 20.7151 & 395378.000 & 433934.000 & 38556.000 & 9.752 \\
\hline
\end{tabular}

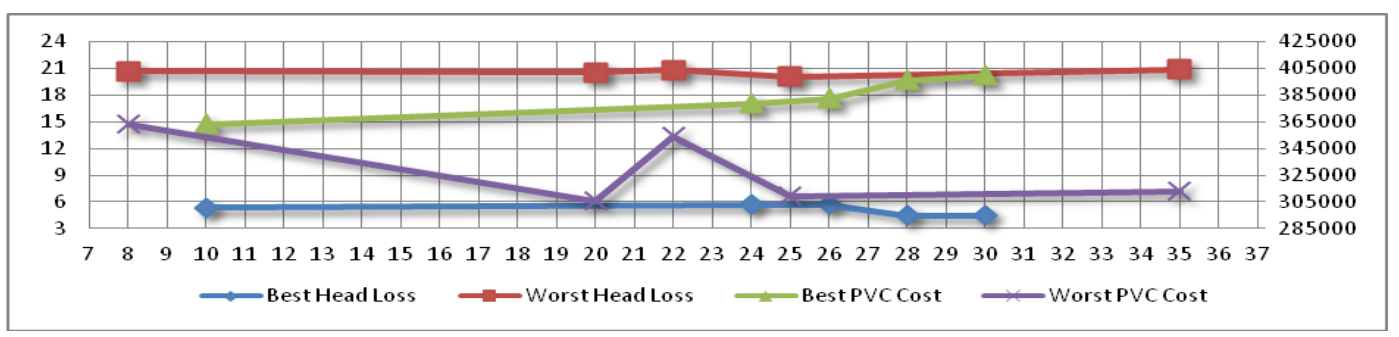

Fig.3: Hydraulically Best/Worst Results for case 1

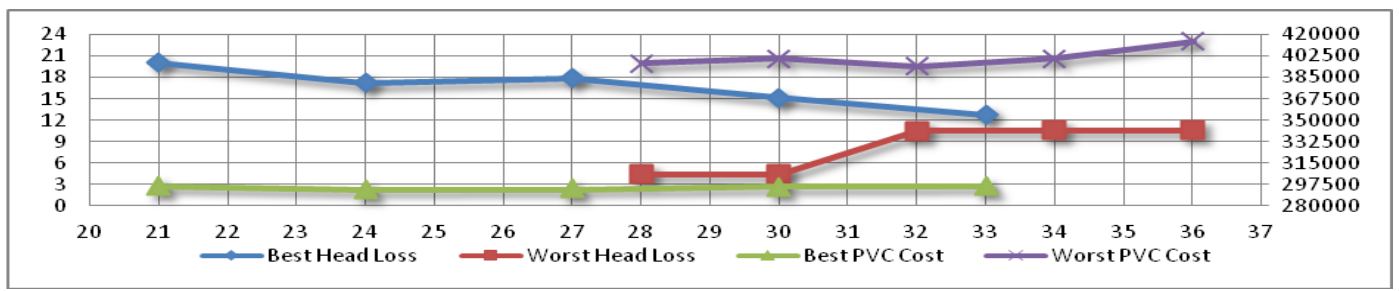

Fig.4: Economically Best/Worst Results for case 1

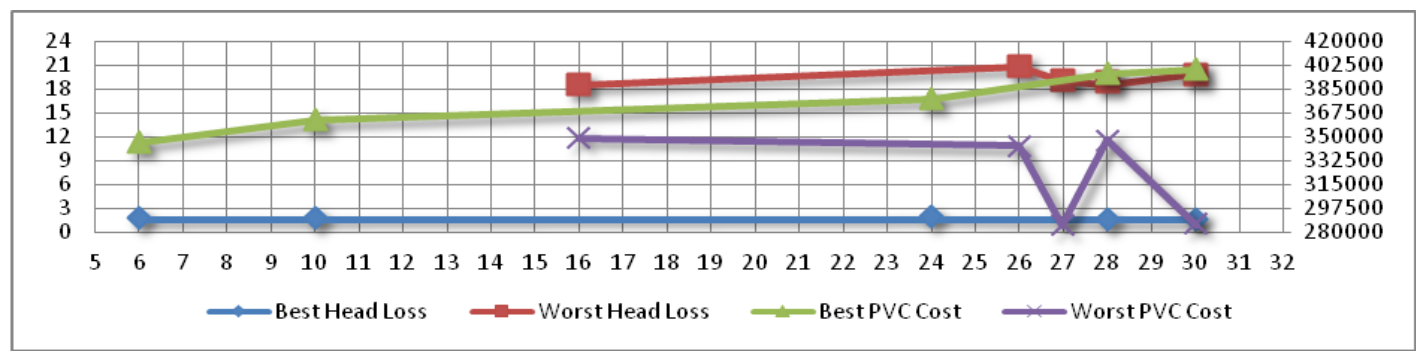

Fig.5: Hydraulically Best/Worst Results for case 2

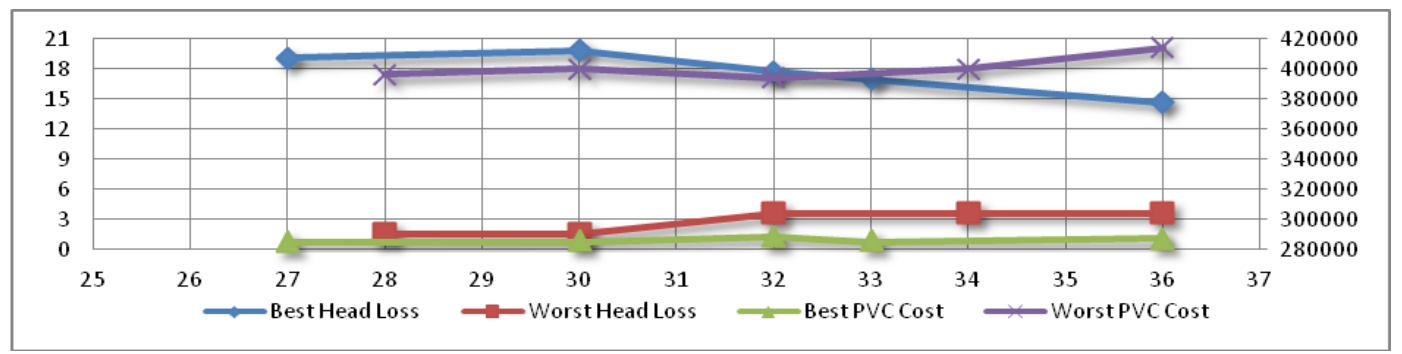

Fig.6: Economically Best/Worst Results for case 2

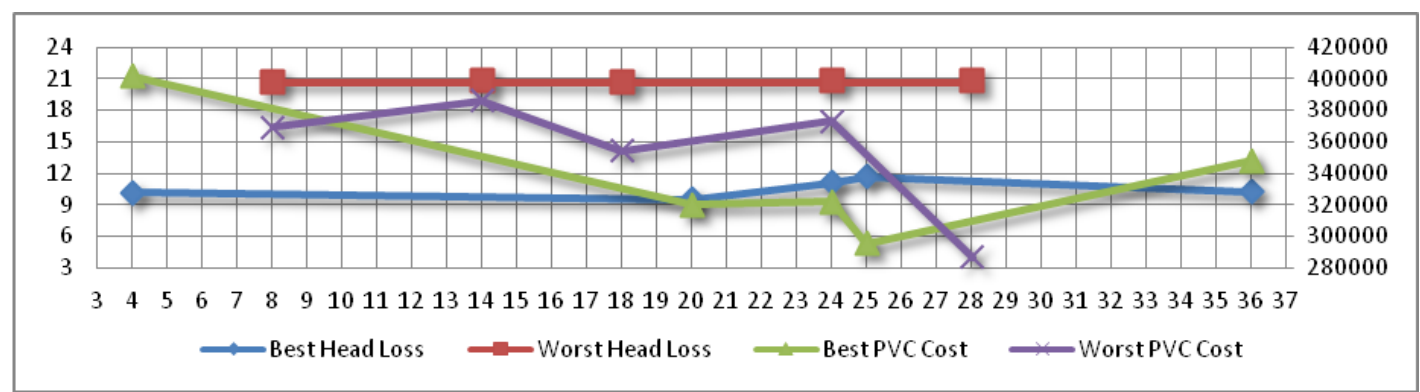

Fig.7: Hydraulically Best/Worst Results for case 3 


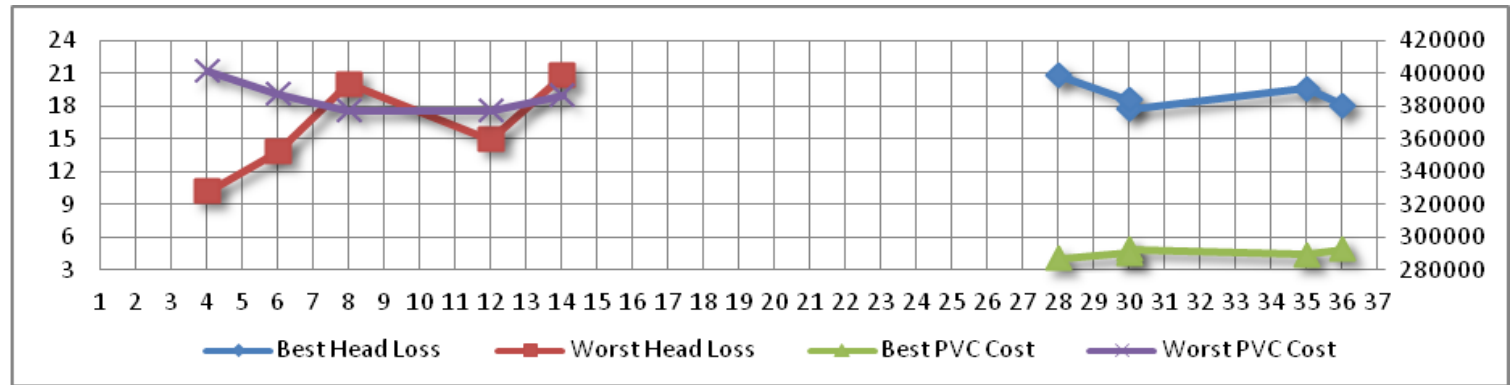

Fig.8: Economically Best/Worst Results for case 3

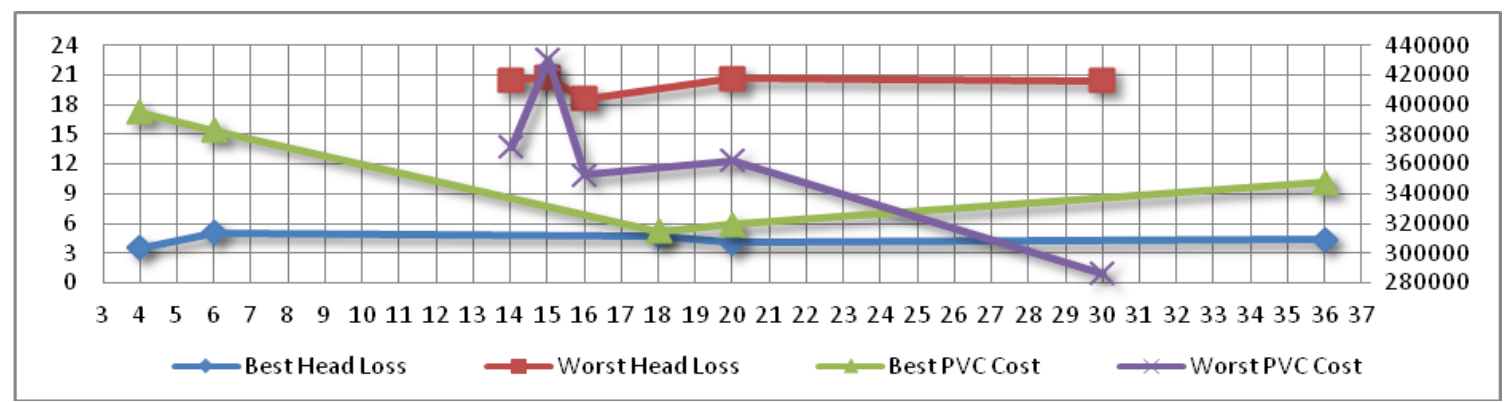

Fig.9: Hydraulically Best/Worst Results for case 4

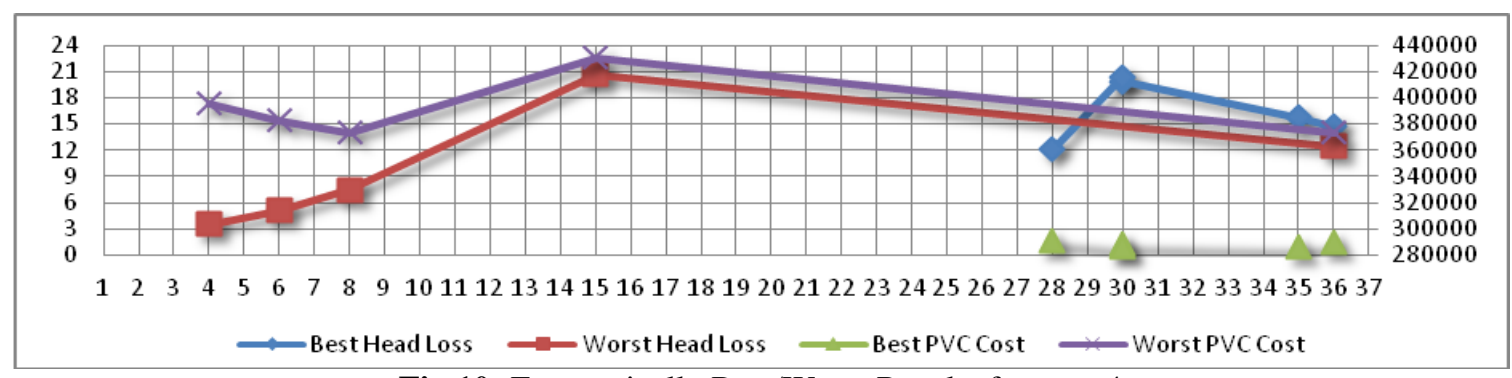

Fig.10: Economically Best/Worst Results for case 4

\section{VII.Conclusions}

As stated earlier there are 69 possibilities for any single case and from the results we can say that there is large variation of cost as well as hydraulic parameter of DIS for different possibilities. For each case best results are stated below.

For first case, field having length of $100 \mathrm{~m}$ and width of $200 \mathrm{~m}$ and source of water at corner, according to hydraulic parameters for best design one needs to divide field into 28 sub-units having 14 columns and 2 rows, for this design head loss is $4.4662 \mathrm{~m}$ and head required at source is $21.9109 \mathrm{~m}$ with cost for PVC is RS. 3,96,278 and for HDPE is Rs.4,67,473 and according to economic results best design is found out for field division into 24 with 3 columns and 8 rows having head loss of $17.1796 \mathrm{~m}$ and head required at source is $35.8048 \mathrm{~m}$ with cost of PVC is Rs.3,12,817 and cost of HDPE is Rs.3,34,235.

For second case, field having length of $100 \mathrm{~m}$ and width of $200 \mathrm{~m}$ and source of water at center, according to hydraulic parameters for best design one needs to divide field into 28 sub-units having 14 columns and 2 rows, for this design head loss is $1.5718 \mathrm{~m}$ and head required at source is $18.7271 \mathrm{~m}$ with cost for PVC is RS. 3,96,121 and for HDPE is Rs.4,67,226 and according to economic results best design is found out for field division into 27 with 3 columns and 9 rows having head loss of $19.1053 \mathrm{~m}$ and head required at source is $37.9230 \mathrm{~m}$ with cost of PVC is Rs.2,85,447 and cost of HDPE is Rs.2,89,913.

For third case, field having length of $200 \mathrm{~m}$ and width of $100 \mathrm{~m}$ and source of water at corner, according to hydraulic parameters for best design one needs to divide field into 20 sub-units having 10 columns and 2 rows, for this design head loss is $9.5449 \mathrm{~m}$ and head required at source is $27.4761 \mathrm{~m}$ with cost for PVC is RS. 3,19,882 and for HDPE is Rs.3,49,132 and according to economic results best design is found out for field division into 28 with 4 columns and 7 rows having head loss of $20.8632 \mathrm{~m}$ and head required at source is $39.8851 \mathrm{~m}$ with cost of PVC is Rs.2,87,210 and cost of HDPE is Rs.2,94,220.

For fourth case, field having length of $200 \mathrm{~m}$ and width of $100 \mathrm{~m}$ and source of water at center, according to hydraulic parameters for best design one needs to divide field into 4 sub-units having 2 columns and 2 rows, for this design head loss is $3.5011 \mathrm{~m}$ and head required at source is $20.7151 \mathrm{~m}$ with cost for PVC is 
RS. 3,95,378 and for HDPE is Rs.4,33,934 and According to economic results best design is found out for field division into 35 with 5 columns and 7 rows having head loss of $15.7852 \mathrm{~m}$ and head required at source is $34.2083 \mathrm{~m}$ with cost of PVC is Rs.2,86,256 and cost of HDPE is Rs.2,90,725.

Therefore, it can be concluded that if field is of $100 \mathrm{~m} \times 200 \mathrm{~m}$ then the best possibility may be 28 subunits having 14 columns and 2 rows and if field is of $200 \mathrm{~m} \times 100 \mathrm{~m}$ then the best possibility may be 4 sub-units having 2 columns and 2 rows, and in both the cases, preferably the source at center, and while comparing these two, the former yields the better results.

From the results it is observed that for case 1 and case 2 , hydraulically best design costs more than the hydraulically worst design and for case 3 and case 4 , hydraulically best design costs less than the hydraulically worst design. Results also indicates that hydraulically best designs and economically best designs are not same, one can see that for first case, second case and fourth case some of hydraulically best designs comes under economically worst designs and for third case economically best design comes under hydraulically worst design, so according to one's requirement whether it may be low investment cost or it may be more concern about head loss, one needs to choose the numbers of sub-units for field division. From this study, it is also observed that DIS design with HDPE material is $0.5 \%$ to $25.6 \%$ more costly than of PVC material. From the obtained results, one can conclude that hydraulic parameters, as well as cost of DIS, highly depends upon the numbers of subunits selected for field division.

\section{References}

[1]. Hassanli, A. M. and Dandy, G. C. (1995), "An Optimization Model for Design of Multiple Sub-unit Pressure Irrigation System" Research Report No.R130

[2]. Holzapfel, E.A., Pannunzio, A., Lorite,I., Silva de Oliveira, A.S. and Farkas, I. (2009), "Design and Management of Irrigation System" Chilean journal of agricultural research 69 (suppl. 1):17-25

[3]. Gujarat Green Revolution Company Limited: Price List w.e.f. 01/01/2016 